Madrygal. Revista de Estudios Gallegos

ISSN: $1138-9664$

\title{
A educación literaria: unha proposta lectora
}

\author{
Paula Cousillas Pena ${ }^{1}$
}

Recibido: 18 de novembro de 2018 / Aceptado: 15 de marzo de 2019

Resumo. A educación literaria é un dos bloques que estruturan o currículo educativo da materia de Lingua Galega e Literatura, no que se contempla un dobre obxectivo: por un lado, o achegamento á historia, ás obras e ás figuras literarias máis salientables; e, por outro, o propósito de acadar lectores e lectoras competentes que continúen, posteriormente, a súa formación lectora. Non obstante, a observación de diferentes programacións educativas, nas que cada docente indica o tratamento da lectura nas aulas, constata que na maioría dos casos soamente se perpetúa o enfoque historicista, e non propicia a querenza pola lectura e a formación de alumnos-lectores. Así, o obxectivo deste traballo consiste en ofrecer unha alternativa metodolóxica que permita incorporar a lectura na aula de maneira diferente a como se vén realizando con frecuencia nos centros educativos. Neste sentido, a través da metodoloxía da constelación literaria, elaborouse unha proposta lectora anual para o alumnado de $2^{\circ}$ da ESO da materia de Lingua Galega e Literatura, co propósito de responder ás necesidades dunha debida formación literaria, na que o alumnado desenvolva non só os contidos e as competencias indicadas no currículo, senón tamén potencie o hábito lector e unha adecuada competencia lecto-literaria.

Palabras chave: educación literaria; proposta lectora; constelación literaria; hábito lector; intertexto lector; canon escolar.

\section{[es] La educación literaria: una propuesta lectora}

Resumen. La educación literaria es uno de los bloques que estructuran el currículo educativo de la materia de Lingua Galega e Literatura, en el que se contempla un doble objetivo: por un lado, la aproximación a la historia, a las obras y a las figuras literarias más destacadas; y, por otro, el propósito de alcanzar lectores y lectoras competentes que continúen, posteriormente, su formación lectora. No obstante, la observación de diferentes programaciones educativas, en las que cada docente indica el tratamiento de la lectura en las aulas, constata que en la mayoría de los casos solamente se perpetúa el enfoque historicista, y no propicia el gusto por la lectura y la formación de alumnos-lectores. Así, el objetivo de este trabajo consiste en ofrecer una alternativa metodológica que permita incorporar la lectura en el aula de manera diferente a como se viene realizando con frecuencia en los centros educativos. En este sentido, a través de la metodología de la constelación literaria, se ha elaborado una propuesta lectora anual para el alumnado de $2^{\circ}$ de la ESO de la materia de Lingua Galega e Literatura, con el propósito de responder a las necesidades de una debida formación literaria, en la que el alumnado desarrolle no solo los contenidos y las competencias indicadas en el currículo, sino también potencie el hábito lector y una adecuada competencia lecto-literaria.

Palabras clave: educación literaria; proposta lectora; constelación literaria; hábito lector; intertexto lector; canon escolar.

\section{[en] Literary Education: a Reading Proposal}

Abstract. Literary education is one of the blocks that structure the education curriculum of the subject Galician Language and Literature, in which a double objective is contemplated: on the one hand, the approach to history, works and the most salient literary figures; and, on the other hand, the purpose of reaching competent readers who will continue their reading training. However, the observation of different educational programs, in which each teacher indicates the treatment of reading in classrooms, states that in most cases only the historicist approach is perpetuated, and does not encourage a taste for reading and student-reader training. Thus, the objective of this work is to offer a methodological alternative that allows to incorporate reading in the classroom in a different way to how it has been done frequently in educational centers. In this sense, through the methodology of the literary constellation, an annual reading proposal has been prepared for students of 2nd ESO in the subject of Lingua Galician Literature, with the purpose of responding to the needs of a proper training literary, in which the students develop not only the contents and the competences indicated in the curriculum, but also enhance the reading habit and an adequate literary-literary competence.

$1 \quad$ Universidade Complutense de Madrid, Centro de Estudos Galegos.

Correo-e: paulacou@ucm.es 
Keywords: Literary Education; Reading Proposal; Literary Constellation, Reader Habit, Reader's Intertext, School Canon.

Sumario. 1. Introdución: a educación literaria. 2. A lectura como potencial educativo. 3. Consideracións da lectura desde o marco lexislativo. 4. As programacións didácticas: a realidade nos centros educativos. 5. A lectura na aula: unha proposta lectora. 5.1. A selección. 5.2. As actividades. 6. Conclusións. 7. Referencias bibliográficas.

Como citar: Cousillas Pena, P. (2019): “A educación literaria: unha proposta lectora", en Madrygal. Revista de Estudios Gallegos 22, pp. 123-134.

\section{Introdución: a educación literaria ${ }^{2}$}

A pesar de que o método tradicional do ensino da literatura se siga perpetuando dentro do sistema educativo, a súa ineficacia para fomentar a querenza pola lectura produciu que se cuestionase a súa utilidade pedagóxica e, desde hai un par de décadas, a lexislación educativa contempla un tratarmento e uns obxectivos parcialmente diferentes con respecto aos contidos literarios.

En contraposición a este método máis tradicional, asentado no estudo da historia da literatura e, por ende, na memorización de contidos históricos e cronolóxicos ao redor do fenómemo literario, o enfoque da educación literaria comezou a abrirse paso como o método máis axeitado dentro do sistema educativo, xa que os seus obxectivos están dirixidos a fomentar a lectura e o hábito lector.

Deste xeito, o estudoso Antonio Mendoza (2004: 59) afirma que son numerosas as voces que insisten en que a didáctica da literatura se caracterizou tradicionalmente por un enfoque historicista, polo que considera que este procedemento debe ser substituído definitivamente por outros enfoques que resulten máis atractivos para chamar á participación activa do alumnado:

Como ya ha sido observado en muchos estudios (Alderson\&Short, 1989; Brumfit\&Carter; Baririentos del Gercio, 1985; Cooper, 1990; Lázaro Carreter, 1992; Mendoza, 2001 y 2002) perdura la inadecuada reiteración de procedimientos didácticos basados en el estudio de contenidos historicistas, en un desmotivador comentario de texto y en la exposición de referencias y valoraciones que reconocidos críticos e investigadores han propuesto sobre las diversas producciones literarias. Estos aspectos resultan de escasa motivación para el alumno puesto que no fomentan la participación creativa e interesada del lector/receptor.

Mendoza é contrario a este enfoque tradicional e considera que o estudo da literatura non debe pasar pola aprendizaxe dunha sucesión de movementos, datas e obras, xa que estes contidos resultan para o alumnado pouco "evidentes" e pouco "significativos". Coida, pois, tal e como mencionaría por exemplo nos anos 90 Daniel Pennac, que o ensino da literatura debe experimentar unha reorientación pedagóxica na que se prime o fomento do hábito lector.

Seguindo esta liña de pensamento, a investigadora Teresa Colomer (1991: 21) insistiu, pola súa parte, na "improcedencia" deste enfoque didáctico e a súa perseverante presenza dentro do estudo da literatura, un sistema que, asegura, debe ser trocado por un enfoque máis acorde coa educación literaria:

A la luz de los conocimientos actuales puede afirmarse que este nuevo marco deberá reemplazar la concepción de una "enseñanza de la literatura" por la de una "educación literaria", entendida esta, tal como viene defendiéndose en las nuevas corrientes didácticas (Coveri, 1966; Lugarini, 1985) como la adquisión de una competencia lectora.

Como se pode apreciar, Colomer tamén apoia este cambio metodolóxico, pois o esencial reside en que o alumnado poida adquirir a competencia lectora, un obxectivo que, certamente, está na base da educación literaria.

En definitiva, como se acaba de ver, desde a investigación pedagóxica insístese en que os estudos literarios deben transformarse para perseguir as bases que sustentan a educación literaria: conseguir que o alumnado sexa receptor activo, que participe, coopere e interactúe directamente co texto, xa que o obxectivo último desta metodoloxía é acadar unha progresiva formación lectora e literaria, que lle permita ao alumnado non só valorar e

Este artigo representa unha síntese do Traballo de Fin de Mestrado titulado A educación literaria: unha proposta lectora, realizado dentro do Mestrado de Profesorado durante o curso 2016-2017 en Santiago de Compostela e titorizado pola profesora Eulalia Agrelo, a quen lle agradezo sinceramente a súa dedicación profesional e o seu trato persoal. 
interpretar a obra de maneira autónoma, se non tamén gozar das lecturas (Mendoza 2004: 15, $26,35)$.

\section{A lectura como potencial educativo}

Tras o marco teórico que acaba de ser exposto, resulta pois evidente que a didáctica da literatura teña de incorporar como elemento esencial a lectura, coa finalidade de adquirir ese hábito lector. Con todo, a lectura non só serve para este fin se non que esta posúe un potencial educativo considerable, posto que é unha das actividades máis completas desde o punto de vista cognitivo, que axuda ao desenvolvemento integral de todas as persoas.

A través dela, tanto da lectura instrumental como da lectura literaria, pódense traballar diferentes aspectos como a capacidade de abstracción, a competencia comunicativa, en especial o desenvolvemento do caudal léxico ou a fluidez na expresión oral e/ou escrita, o sentido crítico, a competencia emocional (Daniel Pennac 1996), a capacidade memorística ou o coñecemento doutros mundos e culturas. Todas estas características producen que se poida falar da lectura como un potencial educativo esencial a ter en conta durante calquera proceso de ensino-aprendizaxe.

Así, tal e como defendía Daniel Cassany (1994: 505), a lectura convértese na ferramenta máis útil dentro do proceso educativo, xa que axuda no desenvolvemento de diferentes competencias, entre as que destaca a lecto-literaria, supón unha fonte de coñecemento inesgotable e fomenta diversas habilidades, tales como a reflexión ou a creatividade.

Neste sentido, o traballo realizado pola Comisión Europea no 2007 titulado Competencias clave para a aprendizaxe permanente, no que se realiza unha descrición das competencias que se deben acadar ao longo do ensino regrado, sinálase, precisamente, a lectura como un elemento relevante dentro do sistema educativo. Así, concretamente, dentro da descrición que se realiza da competencia de aprender a aprender, sinálase a lectura como unha "capacidade básica fundamental necesaria para a aprendizaxe" autónoma do individuo. Isto quere dicir que a lectura é unha compoñente esencial no proceso de ensino-aprendizaxe que axuda, non só a aumentar o coñecemento en diferentes áreas, senón tamén a incrementar outras habilidades, incluso noutras competencias, como en comunicación lingüística ou en conciencia e expresións culturais.
Así mesmo, resultan reveladoras as declaracións da antropóloga Michèle Petit, quen desde os anos 90 do século pasado, investiga sobre a implicación da lectura na construción do ser a través da análise da experiencia persoal con lectores. Petit considera que a lectura é un produto cultural que contribúe á formación de persoas "cidadás", isto é, críticas e reflexivas coa sociedade, polo que a lectura é un ben esencial ao que todos deberiamos acceder. Así e todo, a antropóloga recoñece que aínda que "a lectura non garantiza nada [porque] non vai solucionar os problemas do mundo, [e] non constrúe forzosamente xente crítica [e] con distanciamento", a lectura convértese nunha necesidade debido a que "quen non pode apropiarse da cultura escrita está marxinado da sociedade" (Mayer 2015).

\section{Consideracións da lectura desde o marco lexislativo}

Polo que respecta á lexislación educativa vixente, os obxectivos e o tratamento que se establecen en relación coa lectura e o seu fomento dentro do sistema educativo resultan certamente escasos e inconcretos. Así, por unha parte, a Lei Orgánica para a Mellora da Calidade Educativa, a LOMCE, non contempla ningunha referencia explícita sobre a lectura e o seu tratamento máis alá do xa recollido anteriormente na Lei Orgánica de Educación, a LOE. Nesta última, tal e como logo describirá a LOMCE, no apartado dedicado ás bibliotecas escolares (artigo 113), inclúe o fomento da lectura como un dos labores que esta debe atender, polo que no punto terceiro deste artigo sinálase que:

As bibliotecas escolares contribuirán a fomentar a lectura e que o alumno acceda á información e outros recursos para a aprendizaxe das demais áreas e materias e poida formarse no uso crítico dos mesmos. Igualmente, contribuirán a facer efectivo o disposto nos artigos 19.3 e 26.2 da presente Lei. (LOE 2006: 68)

Os artigos que se acaban de mencionar na cita, o 19.3 e o 26.2, fan referencia ao apartado de Criterios pedagóxicos e, en ambos os dous casos, incídese na idea de fomentar o hábito lector mediante a dedicación dun tempo diario a esta tarefa.

Por outra parte, no Real Decreto 1105/2014, polo que se regula o currículo da ESO e do Bacharelato, non se aprecia tampouco ningún cambio significativo, simplemente se reitera 
unha vez máis a necesidade de incorporar un tempo dedicado á lectura. Así, nos artigos 11 e 25 , nos que se marcan os obxectivos para a ESO e o Bacharelato respectivamente, faise unha breve referencia á adquisición do hábito lector. $\mathrm{Na}$ educación secundaria establécese como un dos obxectivos:

Comprender e expresarse con corrección, oralmente e por escrito, na lingua castelá e se a houber, na lingua cooficial da Comunidade Autónoma, textos e mensaxes complexas, e iniciarse no coñecemento, a lectura e o estudo da literatura. (RD 1105/2014: 117)

Neste mesmo decreto, a única novidade pódese encontrar no artigo 29 referido ao Bacharelato, xa que neste se indica que dentro do proceso de aprendizaxe "as administracións educativas promoverán as medidas necesarias para que nas distintas materias se desenvolvan actividades que estimulen o interese e o hábito da lectura e a capacidade de se expresar correctamente en público" (RD 1105/2014, 2015: 192).

Polo que respecta propiamente ao currículo educativo deste, e en concreto na materia de Lingua Galega e Literatura, no bloque 5 dedicado á literatura, e que leva de maneira significativa o título de Educación literaria, asúmese como obxectivo:

Facer dos alumnos e das alumnas lectores e lectoras competentes, con implicación nun proceso de formación que continúe ao longo de toda a vida. Ademais, o alumnado achegarase á historia da literatura galega, así como ás súas obras e aos seus autores e ás súas autoras máis salientables, e recoñecerá a vinculación destes produtos literarios coa historia de Galicia. (RD 1105/2015, 2015: 26817)

Non obstante, aínda que tampouco se especifique de maneira máis concreta, desde o currículo tamén se asume a responsabilidade de crear o hábito lector entre o alumnado. Con todo, ademais deste obxectivo xeral, os estudos da literatura tamén se atenderán desde unha perspectiva máis tradicional, centrados no saber histórico da literatura. Consecuentemente, isto provoca que dentro da planificación curricular no período da ESO existan obxectivos diferentes dependendo da etapa, o que provoca un cambio metodolóxico, pois o fomendo da lectura é un obxectivo marcado soamente para o primeiro ciclo da ESO, ao que corresponden os cursos de primeiro e segundo.
Finalmente, o documento que cabe destacar verbo da regulación da lectura é a Orde 65/2014 do ano 2015 do Ministerio de Educación, Cultura e Deporte (MECD), pola que se describen as relacións entre as competencias, os contidos e os criterios de avaliación na educación primaria, na educación secundaria e no bacharelato. Concretamente, e debido á súa estreita relación, é no apartado de competencia en comunicación lingüística, onde se recoñece a lectura como unha ferramenta clave para o propio desenvolvemento desta e como instrumento básico para o acceso a outras áreas do coñecemento. Polo que se indica que "[é] especialmente relevante no contexto escolar a consideración da lectura como destreza básica para a ampliación en comunicación lingüística e a aprendizaxe. Así, a lectura é a principal vía de acceso a todas as áreas" (MECD Orde 65/2014, 2014: 6992).

Se ben aquí non se fai mención ao valor da lectura máis alá da súa consideración instrumental, a seguir, indícase que o obxectivo principal da lectura no eido educativo debe ir, desde o recoñecemento e a valoración do canon literario, ata, e principalmente, a consideración desta como fonte de referencia, tanto para o goce persoal como para a aprendizaxe. Neste sentido, a orde finaliza incidindo en que en cada centro debe deseñarse un plan estratéxico para sistematizar a actividade lectora a través de diferentes proxectos, como son o Proxecto Lingüístico de Centro, o Plan Lector ou o Plan de Biblioteca (Orde 65/2014, 2015: 6992).

En definitiva, pódese afirmar que o marco lexislativo, nas súas sucesivas leis e decretos, non concreta as actuacións que se deben realizar en cada etapa educativa ao respecto do fomento da lectura, a pesar de que, moi superficialmente, mencionan a súa importancia. Desta maneira, e ao mesmo tempo, pódese concluír que a planificación da lectura, a súa incorporación na aula e o logro dos seus obxectivos en relación co enfoque da educación literaria, convértese nunha responsabilidade do profesorado, que será quen deba deseñar as diferentes medidas pertinentes para tales fins.

\section{As programacións didácticas: a realidade nos centros educativos}

A pesar do que establece a lei, a realidade nos centros educativos soamente se pode comprobar a través da investigación sobre a praxe 
docente dos propios centros. Desta maneira, coa finalidade de avaliar o cumprimento da lei educativa, colléronse ao azar para este traballo un total de $12^{3}$ programacións didácticas, pertencentes case todas elas ao curso 2016-2017, da materia de Lingua Galega e Literatura ${ }^{4}$.

En síntese, tras a revisión de todas estas programacións, pódese apreciar que a dinámica empregada para levar a lectura a aula non se corresponde co enfoque da educación literaria e, por tanto, tampouco están en consonancia cos obxectivos que as propias programacións recollen, extraéndoas automaticamente da lexislación educativa, e reflectindo nestas diferentes eivas e contradicións. Neste sentido, en moitos casos continúa a predominar un tratamento tradicional da lectura, presentándose un libro único obrigatorio por avaliación con cadansúa proba, normalmente de carácter escrito, que conta un $10 \%$ da nota final. Noutras programacións, aínda que se pode albiscar certa renovación no tratamento da lectura, ben porque ofrecen máis opcións de escolla, ben porque propoñen actividades relacionadas cos libros suxeridos, segue presente igualmente a lectura e a súa avaliación e, por tanto, esta non recibe un tratamento totalmente integrado dentro da aula e adecuado para o fomento dos obxectivos que pretende a educación literaria.

Por tanto, perante esta realidade resulta necesario intentar deseñar outras alternativas metodolóxicas, que sexan acordes cos principios e cos obxectivos da educación literaria, sinalados ademais desde o marco lexislativo. Desde esta perspectiva, débense ofrecer propostas que proporcionen a posibilidade de integralas na aula, non como unha simple tarefa complementaria e obrigatoria da materia; e que teñan entre os seus propósitos: a formación integral do alumnado, acadar os obxectivos da competencia lecto-literaria e o fomento do hábito lector. Ao mesmo tempo, débese ter en conta que a proposta ten de ser flexible, transversal e variada, na que se considerarán, principalmente, o nivel cognitivo-evolutivo do alumnado e os seus gustos, mais sen perder de vista os contidos curriculares (Cerrillo 2013: 27).

\section{A lectura na aula: unha proposta lectora}

Antes de ofrecer calquera alternativa e, en concreto, a proposta deste traballo, cabe considerar previamente os criterios aos que se atende durante o proceso de selección das obras dun centro educativo ou, o que é o mesmo, sobre a conformación do canon literario escolar.

Partindo da teoría dos polisistemas de Even-Zohar, na que se defende o carácter fluctuante na consideración das obras como canónicas, posto que calquera pode ser canonizada ou descanonizada en calquera momento histórico, cabe apuntar que existen diferentes axentes canonizadores, tales como a propia escola, a cal

foi un dos elementos importantes na construción de canons, pois nela formábanse, a través dunha tradición de estudos, antoloxías e historias literarias, que ordenaban, xerarquizaban e impuñan, por medio da educación, un canon por épocas. De feito, eran elas que canonizaban autores e obras. (Roig 2010: 76)

Con todo, e tal e como prosegue a profesora Roig, actualmente ao lado dos factores escolares existen esoutros extraescolares, "que actúan directa ou indirectamente como mediadores entre as obras e o público [...] e, por tanto, poden acabar creando canons seguindo os seus intereses" (Ibid. 77). Paralelamente, o canon escolar tamén se conforma como unha sorte de obras seleccionadas de maneira arbitraria e, por tanto, de xeito moi similar a como se conformaron tradicionalmente os canons literarios. Con todo, o canon escolar debe ser un canon amplo, xeneroso, variado en xéneros, correntes e tendencias e constituído por obras de indiscutible relevancia, que axuden ao desenvolvemento da competencia literaria (Mendoza 1994: 669). Ao mesmo tempo, debera

Ser el resultado de un amplio y tendido debate sobre cuales son las obras literarias más apropiadas por su calidad literaria y significación histórica, por su adecuación al itinerario lector, por su empatía y gusto de los lectores y por su capacidad para la formación del lector competente y la educación literaria del mismo. (Cerrillo 2013: 27)

Tres por cada provincia da comunidade autónoma galega.

Sendo consciente de que a mostra analizada é pequena, resulta igualmente significativa e bastante representativa do estado actual da lectura dentro do sistema educativo galego. As programacións e os centros que foron obxecto de pesquisa poden ser consultados no apartado bibliográfico deste traballo. 
Isto quere dicir que o canon literario, e como conseguinte, calquera proposta ou alternativa lectora que se planifique, debe ter en conta esta serie de criterios de selección para que sexa apropiada e significativa desde o punto de vista educativo. Neste sentido, e seguindo a Cerrillo, o canon ha de ser dinámico, plural, modificable e adaptado ao nivel educativo en que se sitúe dita proposta (Ibid. 27).

Asemade, Cerrillo continúa a súa argumentación sobre a conformación do canon escolar, sostendo a importancia que posúe a presenza de clásicos neste, pola súa riqueza literaria e a súa transcendencia como referente colectivo do noso patrimonio cultural (Sotomayor 2015: 12); ben sexan na súa versión orixinal, ben mediante algunha adaptación, e tendo en consideración a etapa educativa concreta na que se encontre o alumnado.

Con todo, a par da relevancia dos clásicos, tamén resulta relevante para a conformación das diferentes propostas, a incorporación de obras pertencentes á literatura xuvenil, posto que esta é fundamental nos inicios da formación lectora, debido á súa adecuación aos potenciais receptores (Cerrillo 2008: 49). Este tipo de literatura funciona como unha ponte entre esta e a literatura de adultos, permitindo que o alumnado vaia creando o seu propio corpus textual e avance progresivamente na adquisición da competencia lecto-literaria, o que axudaría a enfrontarse posteriormente a outro tipo de textos de maior complexidade estrutural ou narratolóxica.

A partir desta consideración sobre a selección de obras que se tivo en conta, a proposta lectora que se presenta a continuación ten como obxectivos principais facer da lectura unha actividade totalmente normalizada e integrada na aula e outorgarlle certo carácter pracenteiro, coa finalidade de que o alumnado poida apreciar a lectura e formar parte activa dela.

Para lograr este propósito, considerouse como a metodoloxía máis axeitada a patentada pola profesora Guadalupe Jover (2009), quen integra a lectura a través das denominadas "constelacións literarias". Este método, permite que o profesorado deseñe unha selección de obras interconectadas do mesmo xeito que se poden relacionar as estrelas na configuración dunha constelación. Así, o itinerario lector que se deseñe seguindo esta metodoloxía de selección, pode estar conectado co resto das obras por diferentes nexos de unión e, por tanto, a través de calquera vínculo que o mediador estime oportuno para realizar a súa propia constelación. De maneira sintética, e como menciona a profesora Jover con respecto ao "como" se debe ensinar literatura e, por tanto, con respecto ás constelacións literarias, considera o seguinte:

En cuanto al cómo, nos hemos pronunciado por el abandono de las pretensiones enciclopédicas en favor de itinerarios hilvanados con diferentes criterios. La metáfora de las "constelaciones literarias" ilustra el modo en que, de manera análoga a como hemos hecho con las estrellas del firmamento, podemos también establecer vínculos más o menos caprichosos entre unas obras y otras, por lejanas que estén en el espacio o en el tiempo, desde nuestra perspectiva de observadores. Lo importante será, en cada caso, que hagamos explícitos los criterios que nos llevan a conectar unos títulos y otros: temas, personajes, época, ámbito geográfico, género o subgénero, etc. (Jover 2009: 11)

A constelación literaria convértese nun dos métodos máis eficaces para incorporar a lectura na aula, xa que permite que a persoa planificadora poida adaptar un programa que responda ás propias necesidades que considere oportunas tratar ou a aqueles temas nos que considere conveniente reparar. Supón, pois, unha enorme potencialidade de adaptación á diversidade existente na aula.

Neste sentido, para unir a selección de obras, elixiuse a compoñente temática como o nexo vertebrador de toda a constelación e é, pois, a Perspectiva de xénero o tema principal que a cruza.

Ao mesmo tempo, para abordar esta temática, establecéronse tres subtemas ou tres elos de lectura, relacionados con este tema principal, un para cadanseu trimestre, que foron escollidos tendo en consideración a reflexión persoal e grupal á que estes poden conducir. En consonancia con isto, decidiuse nomear o elo primeiro como o $E u$, no que se engloba o tema da cultura xuvenil e todas as preocupacións desta etapa, por seren do interese do alumnado; o Nós é o segundo elo, no que se recolle unha selección de obras, e onde se abordan diversos aspectos relacionados coa identidade social e cultural máis próxima e, por tanto, que nos definen como unha colectividade diferenciada; e, por último, o elo do Todos, que inclúe temas relacionados co conxunto da poboación arredor dunha das maiores problemáticas ás que se afronta o ser humano como especie, os conflitos sociais e as guerras. 
Á parte da metodoloxía, esta proposta defínese por estar orientada para o $2^{\circ}$ curso da $\mathrm{ESO}^{5}$ da materia de Lingua Galega e Literatura, e está pensada para que se poida executar ao longo de todo o ano académico, xa que se trata dunha proposta anual, tanto na aula como fóra dela co traballo individual.

Por último, a proposta lectora está conformada, por un lado, pola propia selección que se mostra a seguir e, por outro, por unha serie de actividades que complementa e completa cada un dos elos e, por tanto, a proposta lectora.

\subsection{A selección}

Como se acaba de expoñer, a constelación literaria pódese dividir en tres trimestres, xa que cada subtema ou elo está pensado para ser abordado en cada un deles, mais sempre tendo presente en todos o tema principal en relación coa perspectiva de xénero.

Desta maneira, o primeiro elo denominado como o Eu, presenta obras que tentan aproximarse ás preocupacións que comezan a xurdir na mocidade, posto que resultan idóneas como ferramenta orientativa e nas que poden atopar respostas ou ampliar o seu punto de vista sobre determinados asuntos. Así, este tipo de obras, que tratan temas como o primeiro (des)amor, os cambios físicos, as dificultades da adaptación social, a rebeldía, o contacto coas drogas ou o acoso, son propicias para que o alumnado encontre na lectura un apoio ao que acudir neste período altamente incerto. Así, as obras que conforman este elo son as seguintes ${ }^{6}:$ A cabeza de Medusa de Marilar Aleixandre (narrativa), O corazón de Xúpiter de Ledicia Costas (narrativa), Anagnórise de María Victoria Moreno (narrativa), Señor das moscas de William Golding (narrativa), Penúltimas tendencias de Carlos Negro (poesía) e $O$ diario vermello de Flanagan de Jaume Rivera e Andreu Martín (narrativa).

O segundo elo, o Nós, está composto por obras que tratan de abordar a dimensión identitaria dos pobos a través de diferentes temas e perspectivas. Con elas preténdese que o alumnado afonde no coñecemento das dinámicas sociais tradicionais que configuran sociedades e culturas diferenciadas. Tal é o caso de por exemplo os costumes ou aínda a lingua, que permiten falarmos dunha identidade colectiva concreta ou, se se quer, de pobos. Así, preténdese chegar con estas obras ao coñecemento e ao recoñecemento do propio, á concienciación social, ou ao respeto pola diversidade cultural: Poetízate de Fran Alonso (poesía), Irmán rei Artur de Carlos G. Reigosa (narrativa), $\mathrm{Me}$ morias dun neno labrego de Xosé Neira Vilas (narrativa), Comedia bifida de Manuel Núñez Singala (teatro), e O segredo da Pedra Figueira de María Xosé Queizán (narrativa), son as obras seleccionadas para este elo.

Por último, o terceiro elo, denominado como o Todos, que se abordaría no terceiro trimestre, recolle obras que aproximan ao lector a diferentes conflitos sociais. A selección recollida neste permite que o alumnado coñeza desde diferentes perspectivas o dano físico, moral e humanitario que supón calquera conflito bélico. A Guerra Civil Española, a I e II Gerra Mundiais ou a Revolución Islámica son algunhas das guerras escollidas para este elo, a través das que se pretende incidir na gravidade das súas consecuencias, ao mesmo tempo que serven de exemplo para entendermos o presente e a nosa directa implicación. As obras son as seguintes: A sombra descalza de An Alfaya (narrativa), Noite de voraces sombras de Agustín Fernández Paz (narrativa), Mañá fará bo día de Luce Fillol (narrativa), Diario de Ana Frank de Ana Frank (narrativa), Persépole de Marjane Satrapi (novela gráfica) e U-49 de Rafael Lema (narrativa).

\subsection{As actividades}

Como se mencionou anteriormente, ademais da selección de obras que conforma a constelación da proposta, esta debe ir acompañada dunha serie de actividades que favorezan a competencia lecto-literaria e que fomente, en

5 Elixiuse $2^{\circ}$ da ESO por ser o último curso no que, desde o currículo, se incide na perspectiva da educación literaria, pois no paso de segundo a terceiro a literatura volve a tratarse desde o enfoque tradicional do estudo da literatura. Neste sentido, resulta clave resaltar neste o fomento do hábito lector e as competencias relacionadas.

6 No traballo orixinal a selección desta proposta lectora estaba formada non só pola listaxe, se non que se incorporaba unha ficha técnica que recollía os daos de caba obra, un resumo argumental desta e aínda un apartado de xustificación, de por que se consideraba adecuada e pertinente a incorporación de cada obra. Porén, debido a problemas de espazo, decidiuse prescindir desta información na elaboración do presente artigo. 
definitiva, a querenza pola lectura e estimule un potencial hábito lector entre o alumnado.

Para isto, e de acordo con estes preceptos que evocan á educación literaria, considérase que o enfoque máis adecuado, non só para lograr estes obxectivos, se non tamén para integrar e favorecer o desenvolvemento de diferentes competencias e contidos curriculares esixidos desde o marco lexislativo, é aquel que propoña actividades que potencien o intertexto lector e que permitan, por tanto, que o alumnado poida chegar á comprensión da obra. Isto quere dicir, pois, que as actividades non estarán dirixidas a contestar unha serie de preguntas que teñan como finalidade a obtención de respostas mecánicas ás que o propio texto responde, senón que o lector ou a lectora obteña, a partir do que xa sabe sobre o mundo, unha significación do texto, o que quere dicir que, tal e como menciona Frank Smith na súa obra Comprensión de la lectura (1983) o alumnado debe ter a capacidade de facer inferencias que lle permita obter eficacia lectora, isto é, xerar e comprobar hipóteses nun contexto significativo.

Así mesmo, e a par da potenciación do intertexto, as actividades irán encamiñadas á consecución doutros obxectivos igualmente relevantes como o fomento da creación literaria, o coñecemento dos aspectos formais que caracterizan os tres grandes xéneros literarios, e a transmisión do valor da lectura como unha ferramenta útil para a reflexión e a construción do individuo, é dicir, para saber ser e estar no mundo.

A modo de exemplo e debido ao acoutamento da extensión deste artigo, incorpóranse neste mesmo soamente as actividades que foron planificadas para abordar o primeiro elo, que corresponde, por tanto, ao primeiro trimestre. Desta maneira, a selección divídese entre unha lectura compartida, A cabeza de Medusa de Marilar Aleixandre, que sería a traballada entre todos na aula e unha lectura individual, traballada polo alumnado de maneira individual.

Tendo en conta o calendario escolar e os contidos curriculares, as actividades deste primeiro trimestre están pensadas para seren executadas ao longo de seis sesións -unha sesión por semana. Ao mesmo tempo, os obxectivos que se perseguen ao longo delas son: comprobar o nivel lector da aula, traballar as características do texto narrativo, poñer a proba o intertexto lector do alumnado e a súa motivación, tentar producir certa reflexión por parte do alumnado, fomentar a participación activa na aula, promover as exposicións orais por parte do alumnado, desenvolver a creatividade, mellorar a procura de información na rede e afianzar o traballo tanto individual como grupal.

Para comezar a traballar na proposta lectora, a primeira sesión estaría dedicada a presentar e xustificar dita proposta e a metodoloxía baseada na constelación literaria, explicando en detalle o tema e os subtemas, que permiten precisamente falar desta proposta como unha constelación.

A continuación, nesta sesión tamén se explicaría, por un lado, de maneira detallada os títulos que conforman o primeiro elo co que se iría traballar; e, por outro lado, cal é o método de traballo seleccionado, tanto para a lectura compartida como para a individual ${ }^{7}$. Ao respecto desta última, a proposta que se suxire é que o alumnado elabore un traballo escrito e unha posterior exposición oral en relación coa lectura individual, un traballo que poderían facer de maneira individual ou grupal. Preténdese que con este traballo poidan abordar diferentes aspectos, tanto desde a perspectiva dunha lectura formal, como desde unha lectura persoal e, por tanto, no que reflictan cuestións como o argumento, a voz narrativa, o tempo, espazos, personaxes, temas, a reflexión persoal, a capacidade de predición dos acontecementos narrados, a opinión sobre a obra, a recomendación da lectura, a relación da obra coa experiencia persoal do lector, entre outras cuestións nas que decidamos incidir.

Na segunda sesión comezaríase a traballar xa coa lectura compartida e, para isto, na primeira parte da clase sería necesario que a persoa docente fixese unha breve presentación da autora da obra, preferiblemente con material videográfico sobre esta ${ }^{8}, \mathrm{e}$, posteriormente,

Como coa lectura compartida xa se iría traballar na aula nas sucesivas sesións, será máis necesario aclarar cal é o procedemento que deberán seguir para traballar coa lectura individual, xa que deberán facelo pola súa conta.

8 O emprego de recursos audiovisuais permiten unha aproximación máis directa coa realidade, pois o alumnado pode poñer cara aos contidos que estamos a dar, conectándoos así cun contexto real no que eles tamén están, e dotándoos, en definitiva, de significatividade. 
implicar o alumnado con preguntas dirixidas para espertar o seu interese pola obra-algunha das preguntas posibles poderían ser: por que pensas que a autora puxo ese título?/ A que fai referencia con este?/ quen é Medusa?/ por que ten ese aspecto? .

Para reforzar e esclarecer as dúbidas que poidan xurdir do debate, poderíase empregar na aula a canción da artista Capicua, titulada Medusa, na que se fai relación a esta figura mitolóxica e a mala sorte que corre a personaxe da canción ${ }^{10}$. Intentaríase, con ela, inducir o seu significado e, xa que logo, relacionar a obra coa canción. Así pois, unha vez que se aclarase quen foi Medusa comezaríase a segunda parte da sesión, introducindo a propia lectura da obra, para o que sería preferible ler os dous primeiros capítulos na aula ${ }^{11}$, posto que é nestes onde se aclara o mito. Para acabar a sesión, a persoa docente remataría formulando algunha pregunta aberta para espertar o interese do alumnado -algunha posible pregunta sería neste caso: que ten que ver este mito coa obra?

No desenvolvemento da terceira sesión, sería necesario que o alumando realizase a lectura, grosso modo, das primeiras setenta páxinas da obra. Así, antes de seguir coa trama, resultaría necesario deixar os primeiros dez minutos iniciais desta sesión para establecer un debate aberto, no que recoller as impresións do alumnado e facelos partícipes activos -algunha pregunta orientativa podería ser: Gustouvos?/ Que sensación vos produciron os feitos?/ Credes que poderían ter evitado o sucedido?/ Considerades que pode ser un caso real?/ Que pensades que vai acontecer agora?/ Seguirán adiante coa denuncia?/ Como as marcará o acontecido na súa vida diaria, no instituto?.

A continuación, o resto da sesión estaría dedicada a profundizar nos elementos narrativos máis destacables e a reparar nos elementos paratextuais e intertextuais da obra: voz narrativa, personaxes, espazo, partes da obra, paratextos, concepto de intertextualidade, entre outros aspectos. Neste sentido, para reforzar o concepto de intertextualidade, proponse un exercicio no que houbesen de procurar na rede referencias ao mito de Medusa e a súa revisión ao longo das diferentes disciplinas e ao longo da historia. Neste sentido, xa que a intertextualidade está presente ao inicio de cada capítulo da obra, poderíase reflexionar sobre as causas que levaron a autora a usar este recurso.

En relación á cuarta sesión, sería recomendable ter avanzada a lectura outras setenta páxinas, posto que ao longo destas son desvelados diferentes temas en relación coa igualdade de xénero, tales como o remordemento ou a culpabilización da víctima, a obxectualización da muller ou a violencia machista. Tendo en conta estes referentes, o alumnado deberá reflexionar sobre o maltrato á muller polo simple feito de selo, tanto físico como psicolóxico, sobre a súa obxectualización e sobre os roles do home e da muller. Para isto, e tras unha breve explicación onde se exemplifiquen casos de discriminación por sexo, o alumnado tería de facer unha colaxe en grupo onde plasmarían evidencias que mostrasen este tipo de agresións e desigualdades, contrapoñendo, ao mesmo tempo, solucións para a súa erradicación. As imaxes ou as frases que seleccionasen faríano a través da revisión de xornais e revistas en papel e dixitais, que lle serían fornecidas.

A quinta sesión estaría dedicada á última parte da obra, polo que sería conveniente que o alumnado lese o resto do libro. Desta maneira, no desenvolvemento da primeira parte desta sesión, abriríase un debate previo para coñecer a opinión e as reaccións do alumnado en relación co desenlace. Vistas as impresións, o resto da sesión dedicaríase á escrita creativa, coa finalidade de implicar ao alumnado neste labor de construción e reconstrución, así como no afondamento do concepto de intertextualidade. Así, para levar isto á práctica, o alumnado en grupos refaría a parte intertextual que inicia cada capítulo por outro encabezamento alternativo, respetando a intertextualidade.

Finalmente, e para dar cabo a este elo, o alumnado debería expor na sexta sesión os traballos que fosen realizados en relación coa

9 As preguntas e os contidos que aquí se suxiren confórmanse simplemente como un roteiro orientativo, que permitirían abordar a lectura propiamente.

10 Esta canción é dunha cantante portuguesa e pódese encontrar facilmente no Youtube. Se houber algún tipo de problema na comprensión, sempre se pode fornecer a maiores a letra escrita da canción, quer na lingua orixinal, quer cunha tradución ao galego.

11 Ler na aula tamén é unha tarefa relevante, sobre todo nas primeiras sesións, xa que permite avaliar o nivel da aula en relación á capacidade lectora. 
lectura individual, coa finalidade de afondar non só nas cuestións técnicas e estruturais da obra, se non para establecer un diálogo no que se puxesen en relación todas as obras deste elo e para que o resto do alumnado puidese coñecer da man dos seus compañeiros as obras que non fosen vistas.

\section{Conclusións}

Ao longo do presente traballo, puídose resaltar a importancia que posúe a lectura para o desenvolvemento das persoas. Así mesmo, realizouse un percorrido pola lexislación educativa que, aínda que sinale como se debe incorporar esta actividade, escasamente contempla cal debe ser o tratamento da lectura dentro do sistema educativo, poñendo en mans do profesorado e dos centros o deber de realizar plans lectores que permitan desenvolver o hábito lector. Pola súa parte, o enfoque metodolóxico que se contempla no currículo con respecto aos contidos de literatura, presenta novidades para a lectura, xa que, a pesar de que siga estando presente o enfoque historicista do fenómeno literario, establécense obxectivos directamente relacionados co novo enfoque da educación literaria, que ten como base o desenvolvemento da competencia lecto-literaria.

Desde esta perspectiva, as propostas lectoras móstranse, por unha parte, como unha ferramenta óptima, que permite o desenvolvemento do hábito lector e a querenza pola lectura; e, por outra, as propostas lectoras aínda se consideran guías necesarias, posto que o profesorado e os centros educativos, tal e como se comprobou nas programacións didácticas, continúan a perpetuar un modelo de lectura escaso, anticuado, ineficaz e pouco acorde con este novo modelo didáctico, que insiste en cargar dunha connotación negativa á lectura, debido á dura penalización que supón non ler o libro único obrigatorio.

En definitiva, e perante a esta eiva, seguen sendo necesarias propostas lectoras que sexan atractivas para o alumnado e que, por tanto, atendan aos seus gustos e inquedanzas, mais sen esquecermos o criterio de calidade literaria e a incorporación de temas, xéneros e obras diversas. Neste sentido, o seguinte traballo pretendeu elaborar unha posible proposta lectora encamiñada para ser posta a proba no $2^{\circ}$ curso da ESO, a través da metodoloxía da constelación literaria e programada para un ano académico enteiro. Á par que a propia selección, a proposta lectora que se deseñou complétase cunha segunda parte, na que se elaboraron unha serie de actividades, coa finalidade de consolidar os obxectivos da educación literaria, principalmente a través do fomento do intertexto lector, sen esquecer ao mesmo tempo as diferentes competencias e os contidos, establecidos desde o currículo educativo.

\section{Referencias bibliográficas}

\section{Marco lexislativo}

Ley Orgánica 2/2006, de 3 de mayo, de Educación. Boletín Oficial del Estado. Madrid, 3 de maio de 2006, núm. 106. Dispoñible en: https://www.boe.es/buscar/pdf/2006/BOE-A-2006-7899-consolidado.pdf.

Ley Orgánica 8/2013, de 9 de diciembre, para la mejora de la calidad educativa. Boletín Oficial del Estado. Madrid, 9 de decembro de 2013, núm. 295. Dispoñible en: https:/www.boe.es/buscar/pdf/2013/BOEA-2013-12886-consolidado.pdf.

Orden ECD65/2014, de 21 de enero, por la que se describen las relaciones entre las competencias, los contenidos y los criterios de evaluación de la educación primaria, la educación secundaria obligatoria y el bachillerato. Boletín Oficial del Estado. Madrid, 29 de xaneiro de 2015, núm. 25. Dispoñible en: https:// www.boe.es/boe/dias/2015/01/29/pdfs/BOEA-2015-738.pdf.

Real Decreto 1105/2014, de 26 de diciembre, por el que se establece el currículo básico de la Educación Secundaria Obligatoria y del Bachillerato. Boletín Oficial del Estado. Madrid, 3 de xaneiro de 2015, núm. 3. Dispoñible en: https://www.boe.es/boe/dias/2015/01/03/pdfs/BOEA-2015-37.pdf.

\section{Programacións didácticas}

IES A Nosa Señora dos Ollos Grandes, Lugo (2016-2017). Programación Didáctica Lingua Galega e Literatura. Dispoñible en: http://www.edu.xunta.gal/centros/iesollosgrandes/?q=taxonomy/term/40.

IES As Lagoas, Ourense (2016-2017). Programación do curso 2016-17 I.E.S As Lagoas Dpto Lingua Galega e Literatura. Dispoñible en: http://www.edu.xunta.gal/centros/iesaslagoas/system/files/Galego\%20 16_17_0.pdf. 
IES Ánxel Fole, Lugo (2017-2012). Programación LOMCE Departamento de Lingua e Literatura Galega. Dispoñible en: http://www.edu.xunta.gal/centros/iesanxelfole/taxonomy/term/51.

IES 12 de Outubro, Ourense (2016-2017). Programación do curso 2016-17 Departamento de Lingua e Literatura Galegas. Dispoñible en: http://www.edu.xunta.gal/centros/ies12outubro/system/files/progr.\%20 Ling\%20galega \%202016-17\%201\%C2\%BA\%2C3\%C2\%BA\%2CESO $\% 201 \%$ C2\%BA\%20BAC.pdf.

IES Félix Muriel, Rianxo (2014-2015). Programación Didáctica do Departamento de Lingua Galega e Literatura. Dispoñible en: http://www.edu.xunta.gal/centros/iesfelixmuriel/system/files/PROGRAMACI\%C3\%93N\%20LGL\%20XERAL\%202014-15_0.pdf.

IES Lucus Augusti, Lugo (2016-2017). Programación de Lingua e Literatura Galegas. Dispoñible en: http://www.edu.xunta.gal/centros/ieslucusaugusti/system/files/Galego.pdf.

IES O Ribeiro, Ourense (2016-2017). Seminario de Lingua e Literatura Galega. Criterios sobre a avaliación e cualificación do alumnado. Dispoñible en: http://www.edu.xunta.gal/centros/iesoribeiro/system/files/Criterios\%20Seminario\%20Lingua\%20Galega\%20e\%20Literatura_0.pdf.

IES Ponteceso, Ponteceso (2016-2017). Programación do Departamento de Lingua Galega e Literatura. Dispoñible en: http://www.edu.xunta.gal/centros/iesponteceso/system/files/PROGRAMACION_LGL22016_17.pdf.

IES Ramón María Aller Ulloa, Lalín (2016-2017). Programación Didáctica de Lingua Galega Literatura. Dispoñible en: http://www.edu.xunta.gal/centros/iesallerulloa/system/files/Programaci\%C3\%B3n\%20 Lingua\%20Galega_2016-2017_0.pdf.

IES Torrente Ballester, Pontevedra (2016-2017). Programación Didáctica de $1^{\circ}$ e $2^{\circ}$ da ESO Lingua Galega e Literatura. Dispoñible en: http://www.edu.xunta.gal/centros/iestorrenteballester/system/files/ PROGRAMACI\%C3\%93N\%201\%C2\%BA\%20E\%202\%C2\%BA.pdf.

IES Torrente Ballester, Pontevedra (2016-2017). Programación Didáctica de $2^{\circ}$ e $3^{\circ}$ da ESO Lingua Galega e Literatura. Dispoñible en: http://www.edu.xunta.gal/centros/iestorrenteballester/system/files/PRO GRAMACI\%C3\%93N\%203\%C2\%BA\%20E\%204\%C2\%BA.pdf.

IES Val Miñor, Nigrán (2016-2017). Programación Didáctica Lingua Galega e Literatura. Dispoñible en: www.dropbox.com/sh/dozu69hhxon77jv/AACBttebRw3Ftowp5VOETEPa?dl=0\&preview=11-DEP_ L_GALEGA.pdf.

Instituto de Bacharelato Arcebispo Xelmírez II, Santiago de Compostela (2016-2017). Departamento de Lingua Galega e Literatura. Programación didáctica. Santiago de Compostela. Dispoñible en: http:// www.edu.xunta.gal/centros/iesarcebispoxelmirez2/node/821\#attachments.

\section{Fontes secundarias}

Cassany, Daniel (1994): Enseñar lengua. Barcelona: Graó.

Cerrillo, Pedro César (2008): "La LIJ y su importancia en la educación literaria", Cuadernos de Literatura Infantil y Juvenil 212, pp. 45-58.

(2013): LIJ. Literatura mayor de edad. Cuenca: Ediciones de la Universidad de Castilla-La Mancha

Colomer, Teresa (1991): "De la enseñanza de la literatura a la educación literaria", Comunicación, lenguaje y educación 9, pp. 21-31.

Comisión Europea (2006): Competencias clave para un aprendizaje permanente [en liña]. Dispoñible en: http://www.mecd.gob.es/dctm/ministerio/educacion/mecu/movilidadeuropa/competenciasclave.pdf?do cumentId=0901e72b80685fb1.

Mayer, Guillermo (2015). Michèle Petit: "La lectura no garantiza nada, no va a solucionar los problemas del mundo. No forzosamente construye gente crítica, con distanciamiento, pero el que no puede apropiarse de la cultura escrita está más marginado de la sociedad (2)", El jinete insomen 13/11/2015. Dispoñible en: http://eljineteinsomne2.blogspot.com/2015/09/michele-petit-la-lectura-no-garantiza_13.html.

Mendoza, A. (1994): Literatura comparada e intertextualidad. Perspectivas para el tratamiento didáctico de la literatura. En P. Guerrero Ruiz, A. López Valero (Eds.), Actas III Congreso internacional de la Sociedad Española de Didáctica de la lengua y la literatura (pp 691-702). Murcia, España: Compubell SL

Mendoza, Antonio (2004): La educación literaria. Bases para la formación de la competencia lecto-literaria. Málaga: Aljibe

Roig, Blanca Ana (2010): "Educação literária e cânon literário escolar", Letras de Hoje: Estudos e debates de assuntos de lingüistica, literatura e língua portuguesa 45/3, pp.75-79. 
Sotomayor, Victoria (2015): "Los clásicos en las lecturas infantiles y juveniles", en B. A. Roig, I. Soto e M. Neira (eds.), Retorno aos clásicos. Obras imprescindibeis da narrativa infantil e xuvenil. Vigo: Xerais, pp. 12-25.

Jover, Guadalupe (coord.) (2009): Constelaciones literarias. Sentirse raro. Miradas sobre la adolescencia. Málaga: Consejería de Educación, Delegación Provincial de Málaga. Dispoñible en: http://www.juntadeandalucia.es/educacion/webportal/abaco-portlet/content/015af83c-3362-4f74-929c-af321e6e6f36. 